\title{
My tongue on your theory: the bittersweet reminder of every-thing unnameable
}

\author{
Rachel Holmes
}

\begin{abstract}
Across research in UK Higher Education, the most immanent demands for quality have taken the shape of the Research Assessment Exercise (RAE, 2008) and the Research Excellence Framework (REF, 2014). Martin (2011) is cautious of the relationship academics have engendered with the process of the REF, asking are we actually creating a Frankenstein monster, becoming complicit in generating quality thresholds and standards that will become our own tormentors? I am taken by the idea of the monster when pursuing alternative discourses of childhood in educational research - fear of its potential to torment seduces me with the promise of dis-order, de-formity, chaos and mutation. The aim of this paper is to resist a fixed, knowable form of 'quality' (in) research, moving between the idea of 'monster' and the formlessness of 'monstrosity' to oppose "the epistemological, ontological and ethical paradigms of reason" (Shildrick, 1996: 2).
\end{abstract}

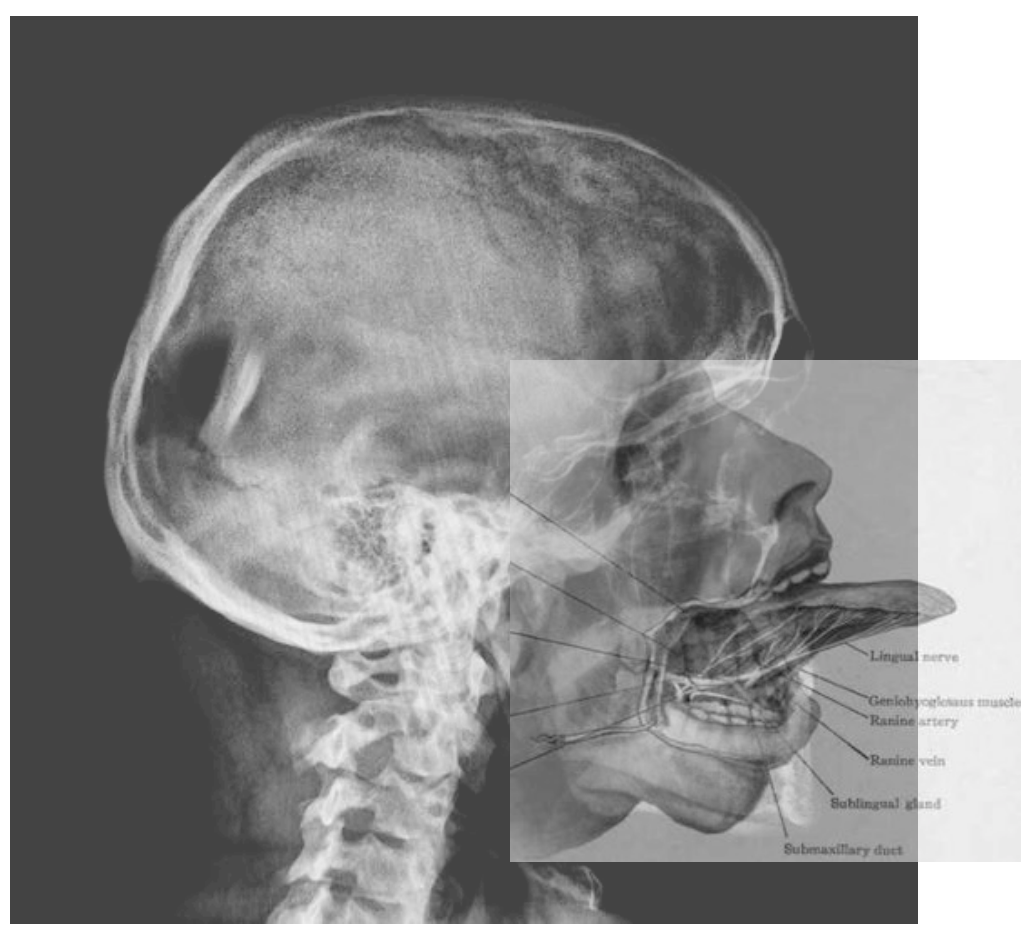

Rudolf Viček, 2011 


\section{Introduction}

Philosophy is [...] a practice of concepts [that] must be judged as a function of other practices with which it interferes. [...] It is at the level of interference of many practices that things happen, beings, images, concepts, all kinds of events (Deleuze)

Across research in UK Higher Education, the most immanent demands for quality have taken the shape of the Research Assessment Exercise (RAE, 2008) and the Research Excellence Framework (REF, 2014). Martin (2011) is cautious of the relationship academics have engendered with the process of the REF, asking are we actually creating a Frankenstein monster, becoming complicit in generating quality thresholds and standards that will become our own tormentors? I am taken by the idea of the monster in research - fear of its potential to torment seduces me with the promise of dis-order, deformity, chaos and mutation. The aim of this paper is to resist a fixed, knowable form of 'quality' (in) research, moving between the idea of 'monster' and the formlessness of 'monstrosity' to oppose "the epistemological, ontological and ethical paradigms of reason" (Shildrick, 1996: 2). I will put the idea of monstrosity to work as a function of qualitative research practices, to insert an "oppositional consciousness" (Braidotti, 2008: 1) at the heart of the debate on anthropocentrically configured 'quality' in educational research. At the level of monstrosity's interference in those practices, I will unravel traditional signifiers that haunt the concept of 'quality', such as logic, normality, purity, objectivity and human-centredness. By disrupting disciplinary boundaries and playing with impurities, I begin to think how I might refuse to discipline the "normal" (Halberstam, 1995: 27), arguing that monstrosity already interferes with the conceptual framings of quality, holding within it, the delights of threat, decomposition and erosion. Deleuze writes, "It is the excess in the Idea which explains the lack in the concept" (Deleuze, 1994: 273). As an idea, monstrosity turns to the excess and leakages that are so often let down by the conceptual constraints of quality in research. It offers the potential of unravelling the bounded concepts that remain staunchly preserved: the organisation of the human body; disciplines; the framings of nature and culture, matter and information. In trying to provoke "an order of being far outside the merely physical in organisation and capacities" (Lovecraft, 1985: 519), monstrosity renders boundaries less certain and always already at stake.

Moving through "my workshop of filthy creation" (Shelley, 2008/1818: 53), I document my dirty dealings with illusion, wade into my desires to keep re-producing the immaculate "god trick" (Haraway, 1988: 582) as I collect and re-organise decaying data to re-create the perfect eugenic-cosmetic corpse/corpus. Following Jones and Stewart (1994), a moment of my tongue on your theory allows me to taste the bittersweet vapours that leak from the excesses and septic sutures that tell a different tale of the reconfigured data corpse. Cannibalising the frames that preserve nature/culture, information/matter urges me to become a boundary-creature, as I document an unravelling humanist body through stories of transdisciplinarity. This paper enacts a 'trans-ing' of transdisciplinarity through its performativity, which as Barad notes, "... is actually a contestation of the unexamined habits of mind that grant language and other forms of representation more power in determining our ontologies than they deserve (2003: 802). 
My imagination moves like wild nomadic prostheses across these performative images to insert themselves into assemblages of Dogfight, the name given to my multiple engagements with the playground game of 'Catch a Girl Kiss a Girl'.

\section{My workshop of filthy creation: tasting monstrosity}

Deleuze and Guattari (1977) observe that it is not the slumber of reason that engenders monsters, but vigilant and insomniac rationality. In the UK, the vigilant web of quality indicators haunting research agendas in HE, becomes the threshold we all seek to demonstrate. Martin (2011) reflects on how academics have developed ways to assess research performance in the REF (2014), evoking the idea of the monster 'you are my creator, but I am your master' - a fraught battle between creator and creation as animation is bestowed upon a lifeless concept that is 'quality'.

Following Stange (2010), as an educational researcher, I become tormented by the monster I have created, as I procure the organic matter of my data to the abstraction that is 'quality', serving as the inert, material base that quality can then "reanimate within its own dynamic artifice" (2010: 312). With some seeping wounds around the edges of prostheses such as language (Derrida, 1997) and vigorously mutating contagions such as identity (Butler, 1990; Bhabha, 1994), knowledge (Lyotard, 1979; Haraway, 1988), power (Foucault, 1977) and truth (Rorty, 1991), my researcher self in relation with objects of my inquiry are kept animated, albeit stuttering and stumbling within excessive bounded forms. The category human(ism) in qualitative research is grounded in the coherence of the researcher's individuality - a singular human form, bound by skin, a coherent, contained, rational being, as Shildrick proposes, the "abstract universal marker of the site of foundational voice, vision, vitality ...The body itself is simply that which is bracketed out, unrepresented, transcended" (1996: 1).

In 2006 I was standing in a playground with a camcorder, recording a group of children playing a game of 'Catch a girl kiss a girl'. As I watched on the digital screen, I tracked one young female in particular being held by a sole male, first her hands are held behind her back, later she is grabbed by her jumper. She shouts to her friends and struggles to pull herself free from his grip. He calls over three of his male friends to help contain her but she tears her arms and body free and so unfolds a fast-paced playground melee of chase and capture.
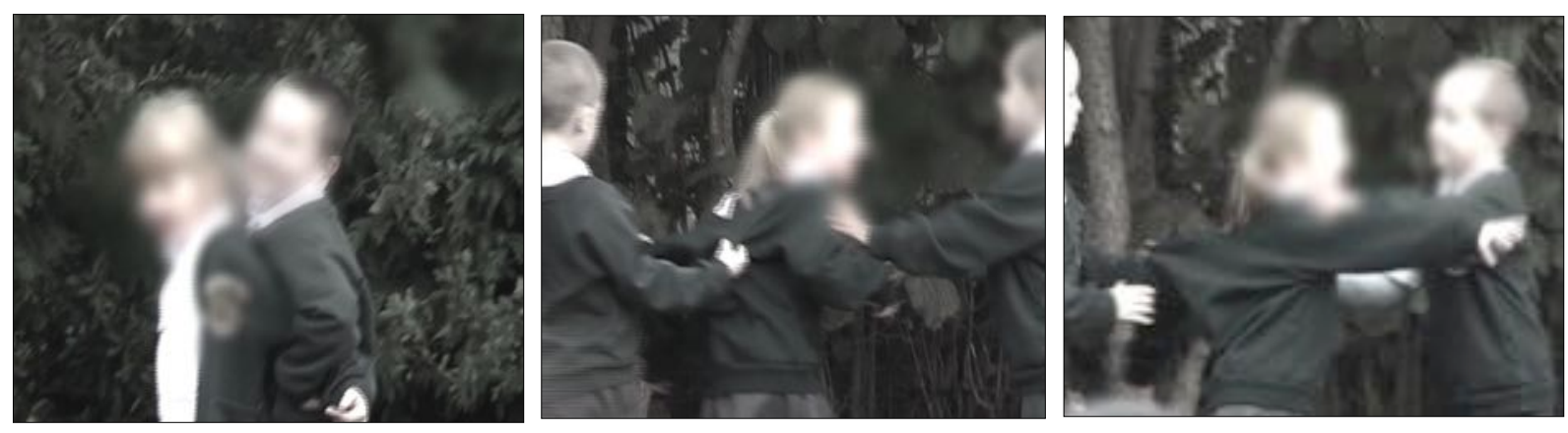

Stills from BAP film (http://www.esri.mmu.ac.uk/resprojects/project_outline.php?project_id=133) 
My disembodied and transcendent "conquering gaze from nowhere," (Haraway, 1988: 581 ) is at work as I 'read' the extract of this event that takes the form of a linear piece, lasting 29.13 seconds 'real time'. In my gathering of visual information, I remain a coherent human subject, the images clearly split apart and distance me as viewer from the children as objects of inquiry. I willingly collude with what Haraway (1988) describes as a wonderfully performed "illusion, a god trick", permitting the fashioning of quality in my workshop of filthy creation, as I edit and reconfigure the 'perfect corpse' - the collection of the most desirable yet nevertheless fragmented and dismembered limbs, behaviour and genetic information to create a body image of children that serves my particular research intentions.

Out of the hodgepodge emerges a curated and carefully crafted series of potential narratives about the playground chase. These narratives seem inscribed into the events I observe, they swirl defiantly around my head, are traced with ink into my notepad and erupt unexpectedly in conversations: boisterous play, children's peer cultures, gendered behaviours and interactions; playground 'games' as exercise, developing the child's power of independent movement, journeys of discovery; theories of animal and human play; inquiry-based, child-centred, experimental learning; the pleasure principle, children's unconscious motivations, creativity and liberation; bodies as sites of gender constitution and relations.

Perhaps my re-presentations of the game of playground chase are already crucially written as I collect the data, read the images, code them and out of seemingly disparate limbs, stitch and re-create a monstrous whole, telling different stories, producing new creatures. The serendipitous lightening bolt animates the desirable quality machine, as Mary Shelley writes, "I saw the dull yellow eyes of the creature open. His jaws opened, and he muttered some inarticulate sounds, while a grin wrinkled his cheeks" (2008: 56).

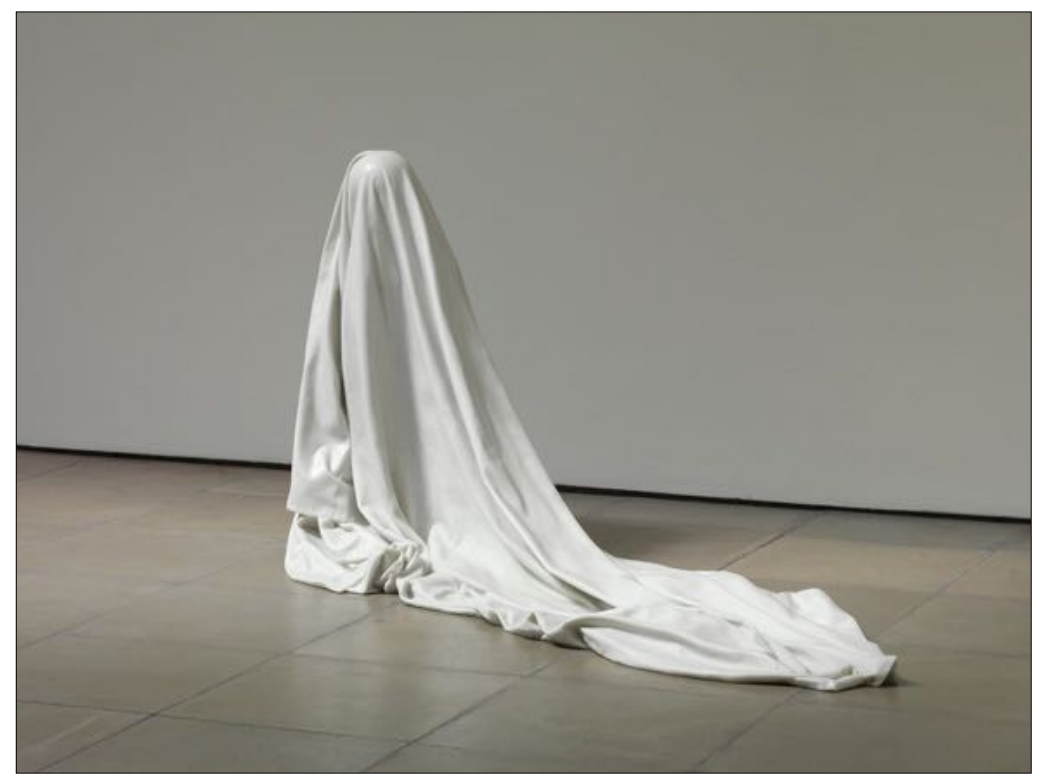

Ryan Gander 


\section{Cannibalising data: a little blood, a little urine, an orgasm or two}

As I turn away from the dissecting slab, breathing in the unworldly stench of the data's empirical death and its gruesome resurrection, I am aware that at the slaughterhouse, some things never die (LeDuff, 2003). Something of the playground data's odour has been ingested into my blood stream and body's fibres. Shildrick writes, “... what monsters show us is the other of the humanist subject..." (1996: 2).

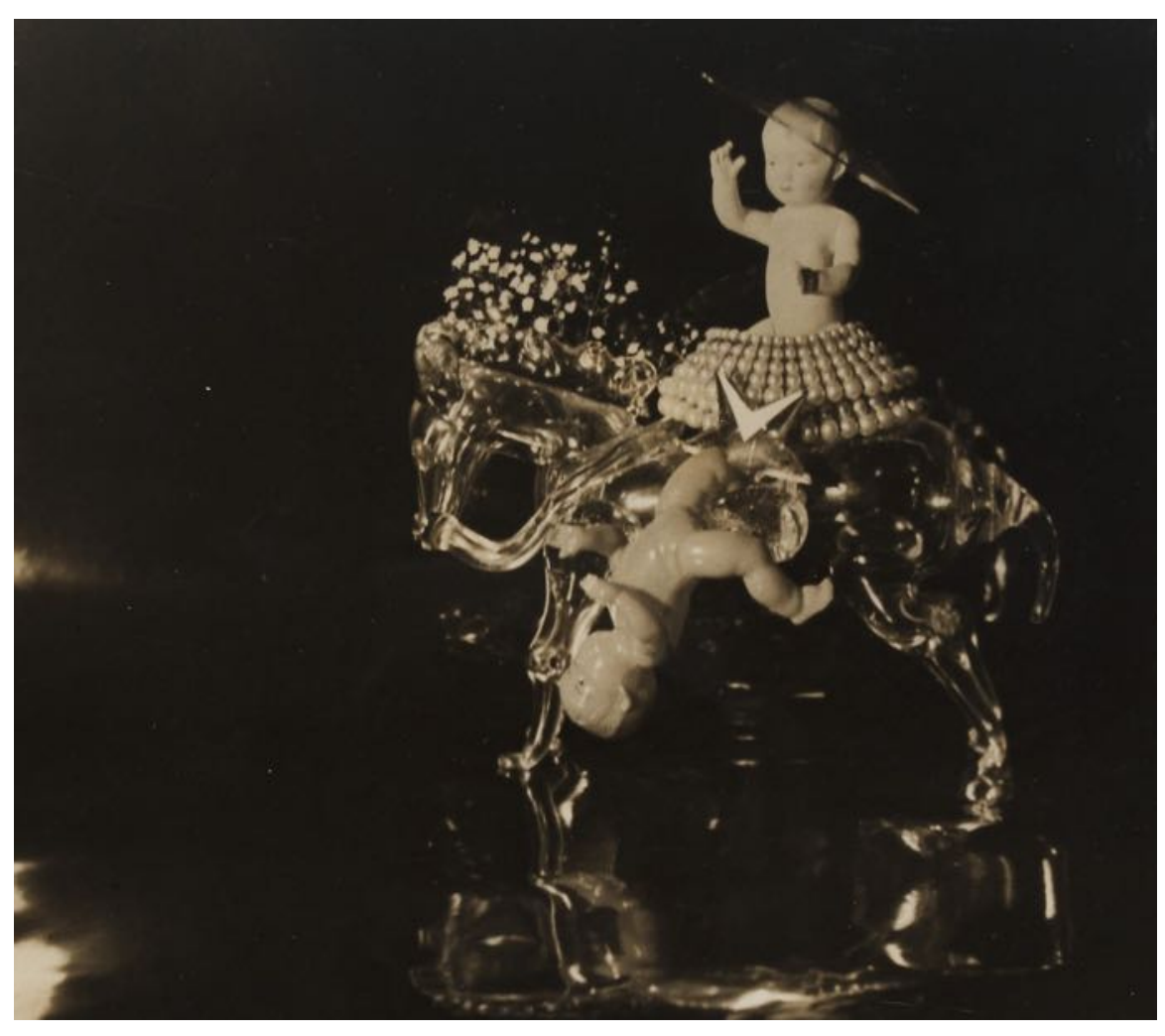

Claude Cahun

Untitled

(Variant of catalogue raisonné plate 209)

1936

Vintage gelatin silver print

$45 / 8 \times 53 / 4$ inches $(11.7 \times 14.6 \mathrm{~cm})$

Dated on verso

(CAHU 29)

I find myself caught wondering how data has become monstrous debris, savagely torn apart, reassembled and strangle (un)recognisable, reaching to the radical otherness at the heart of my humanist researcher-self. I momentarily recall a conversation with a colleague where we salivated over our cannibalistic delight in data. As animals feeding on the flesh of our own species, we worried that we were in danger of making data a tasty dish, concerned about our delight in data and wondering where is the ethics in such delight? We feared being more concerned with getting a pound of flesh from data so as to satisfy our lascivious pleasure, our own masticatory, masturbatory practices. The thought of bodily fluids lubricating the mixing of matter and information became a fascinating preoccupation. 
Following Golding (2012: 3), a little blood, a little urine, an orgasm or two, not to mention cannibalism goes a long way to disrupt the otherwise self-sealing pronouncements on what or who could be considered researcher. I am plunged into the depths of my imagination that desires to exceed my body, already deeply entangled in the playground event. I find the data gnawing on my body, my tongue all over the screen, being swallowed by time and the pace of the playground chase, beginning to feel my self unraveling, no longer a researcher in singular human form, bound by skin. I begin to sense, "...blood and guts oozing from the fissures in [my] skin, an excess of existence, exceeding representation, and hence appearing to others as a chaotic spillage from [my] own representational shell" (Gigante, 2000: 566).

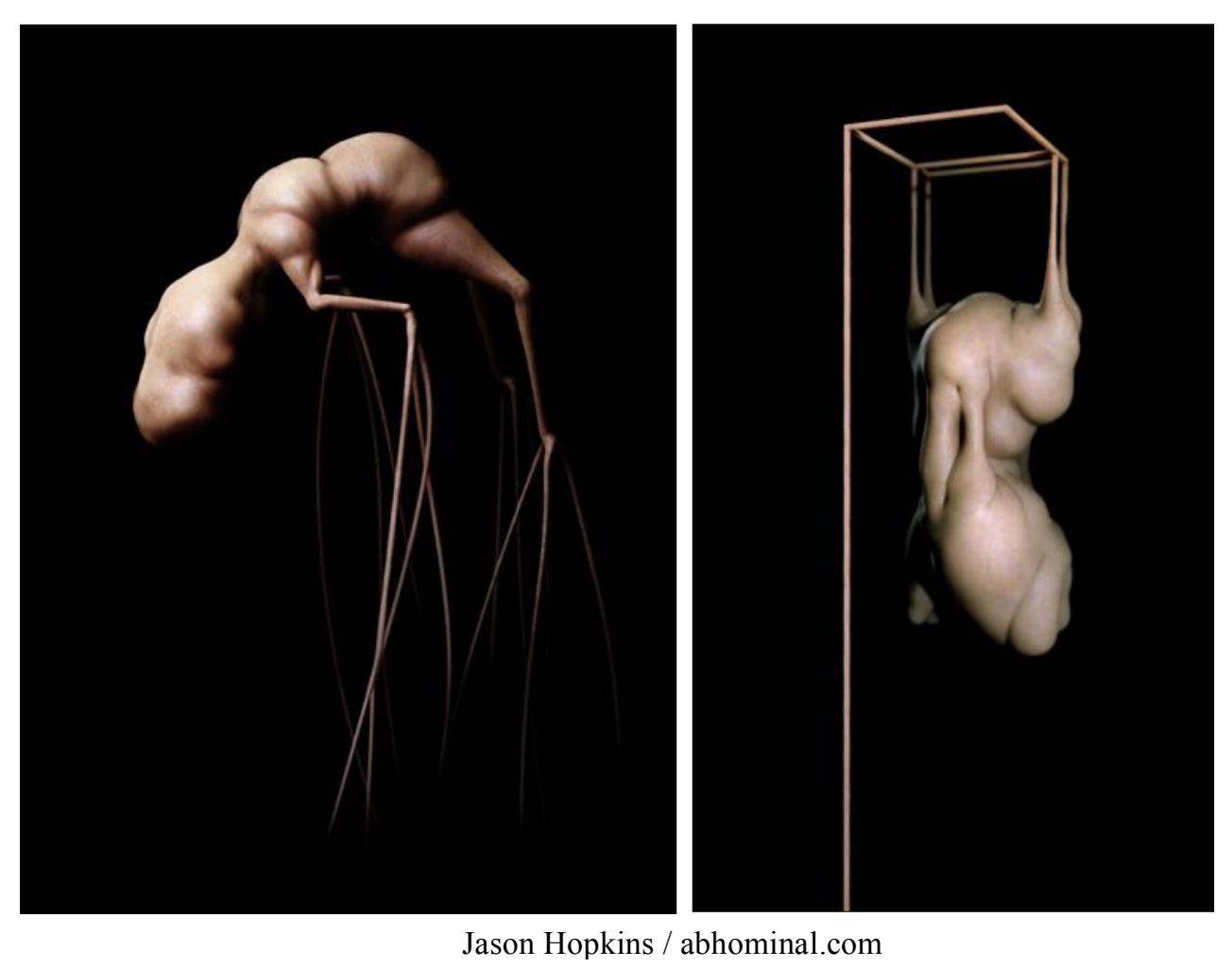

Slowly unraveling, I realise the data and my body have never really been distinct from each other. Deleuze and Guattari propose that "It's not a question of being this or that sort of human, but of becoming inhuman... unraveling your body's human organization" (1994: 11). I wonder how I can begin to re-formulate imponderable, unnoticeable possibilities of unraveling? Perhaps something more is needed, as I turn to the place where MacLure (2011) proposes mastication and speaking change place. After analysis, I continue to ooze traces of the data, decomposing flesh and bodily debris, scraps of theory, time and space, septic reminders of the vibrant assemblages left behind in my retelling of the playground melee. I work to clean away the offal and entrails, remnants of previous research papers and particular data assemblages, when my tongue passes over something, it moistens. I find myself in the 'intersections of the concepts of the human, of the non-human, of science and of monstrosity' (Berns, 2013: 187). I lick the ink bleeding through the fibres of Mary Shelley's letters, touch the potent mix of biological grime, 
fragments of wood and rotting epidermis forced into every splintered sear across Victor's workshop bench. My tongue moves across matter and information as I begin to grapple with the sticky consistencies leaking from the many re-assemblages of 'quality' in educational research.

\section{Matter and information: desiring secretions}

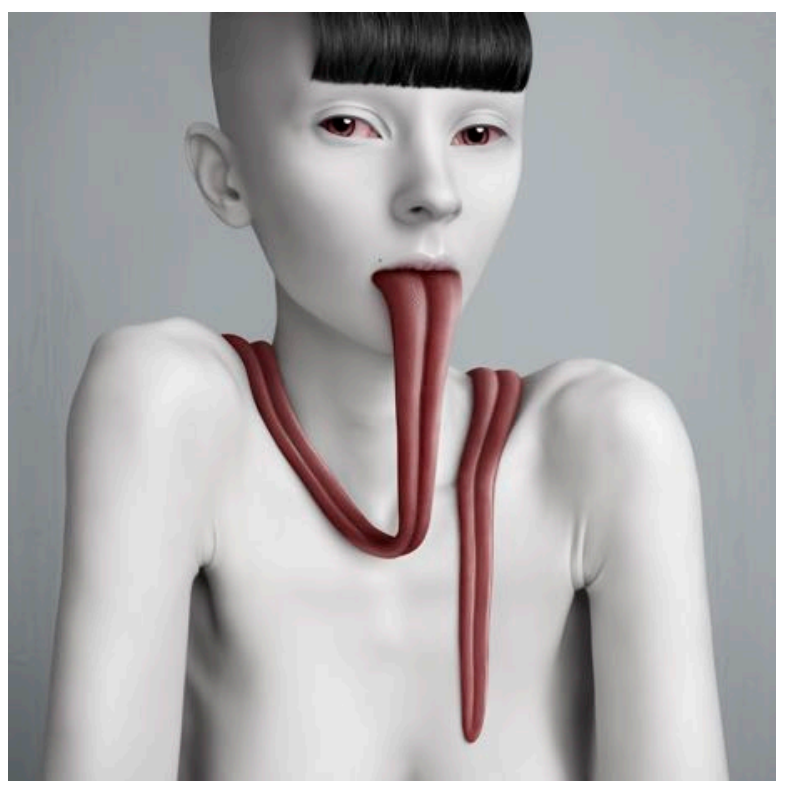

Tie, 2007, Oleg Dou

Entering what Bataille (1930) considers my most living part, the bittersweet reminder of every-thing unnameable that has been discarded in the dissecting room oozes restlessly over my tongue. Hosu Kim's 'mouth-work' (2007: 35), evokes parched, impoverished, displaced, broken, bruised and unrecognised tongues, where on the surface, as MacLure writes, the exertions of 'dumb matter' and the logic of the symbolic order (ie language) are played out (2011: 1001). My tongue reaches outwards with an already complex fleshly surface, to desire, touch and cannibalise the movements of information, leakages, connections and experiences of the playground melee. This image of thought puts pressure on the interfaces of "matter and information, life and non-life, nature and artifact, organic and inorganic, creator and creature, the evolved and designed" (van den Belt, 2009: 259).

The mixture of body, child, theory, time and space, camera, clothing, force and language all become interesting masticatory assemblages of life and non-life, nature and artifact. My tongue desires the taste of these mixtures, saliva lubricates intensive sensations and affective textures, evoking the surprisingly wet stickiness of new empiricisms and posthuman theory as it drips seductively through my lips. An uncertain field of uncanny, negotiated relations opens up. Barad (2012) might suggest an infinity of possibilities is at the core of mattering in this encounter, "Matter is never a settled matter. It is always already radically open" (2012: 213). How can this intimate, indeterminate prosthetic interface of tongue-theory keep a sense of unsettled matter moving? Graham insists that monstrosity embodies a "simultaneous demonstration and destabilization of the 
demarcations by which cultures have separated nature from artifice, human from nonhuman, normal from pathological" (2002: 12), so perhaps my tongue on your theory evokes the ever-moving states of being and abstract; taste and preference; wet and dry; flesh and practice, seeming incongruities, that glide over complex and troubled surfaces to reveal the radical openness already always apparent.

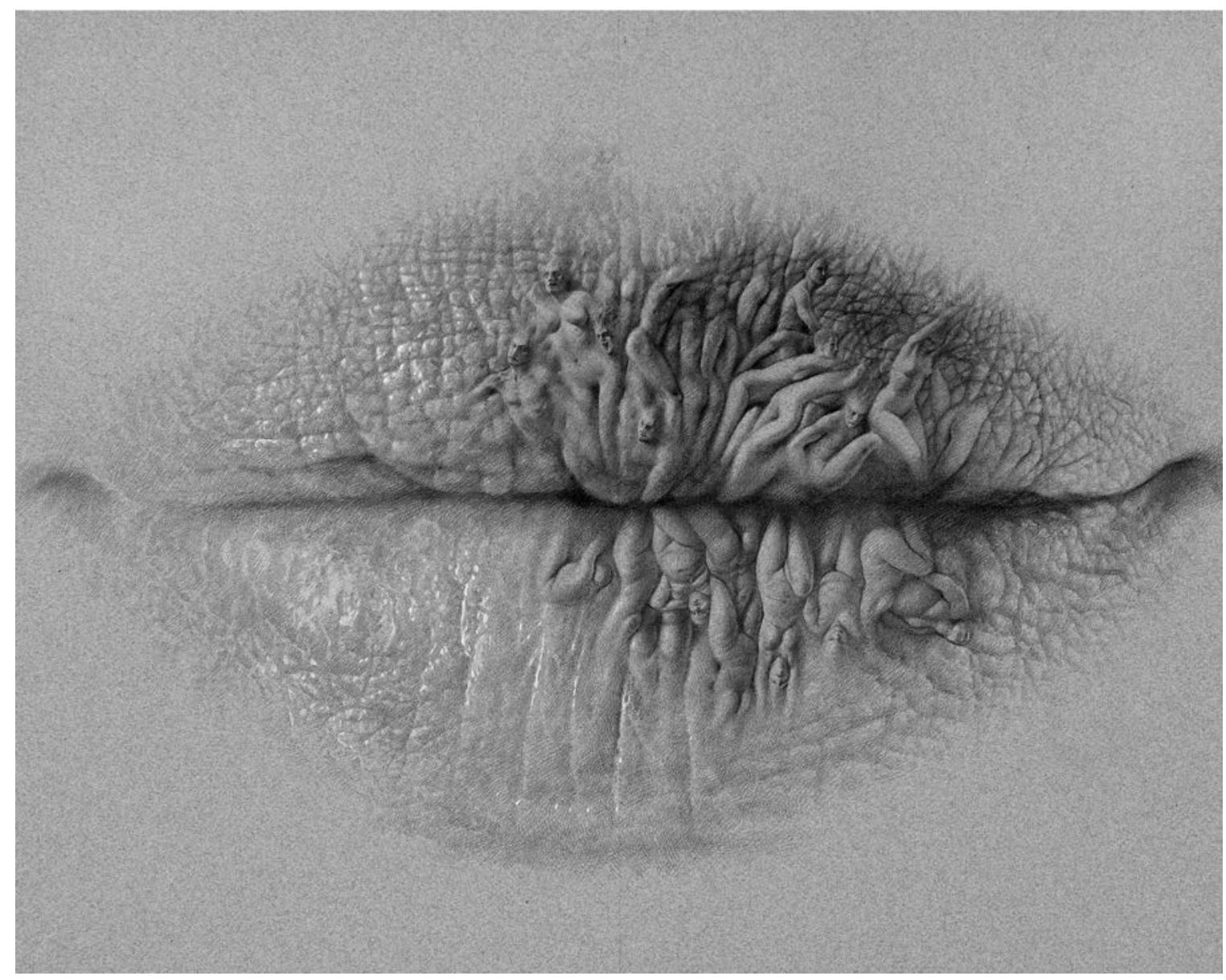

wealth (lips series 5.11) / 2011 / pencil on paper / 25.6" x 19.8” / 65 x 50cm, Christo Dagorov, 2011

My mouth-work profusion senses (con)fusion as dumb matter and wild guttural sounds erupt through vocal cords, entangling the tongue to produce the damp fleshly orifice in irresistible intra-activity with the logic of language. My tongue colonises theoretical cells, conjuring an 'interspecies kiss', what Turner (following Haraway) might describe as “... a co-constitution and reproduction that exceeds species" (2010: 71). I am taken by the possibilities of matter encountering information, organic licking inorganic, creator entangling with creature, materializing in what Barad (2003) calls intra-activity. I contemplate how this interspecies kiss might help me undo my body to radically unthink its encounter with theory leaking from the inside of the playground data. 


\section{Leaky boundaries, transgressive signifiers: the irruptive manifestation of the monstrous}

If, as Butler proposes, "one is not simply a body, but, in some very key sense, one does one's body" (1990: 272), and being individual means to be human, unitary and autonomous, then to undo my body, lose my individuality means to go beyond, exceed, to be somehow trans-human, monstrous. Like Victor Frankenstein and his chaotic Creature, as ethnographer, with my body, the children, camcorder, playground, time and space, perhaps all become (con)fused in the co-constitutive production of 'data'.

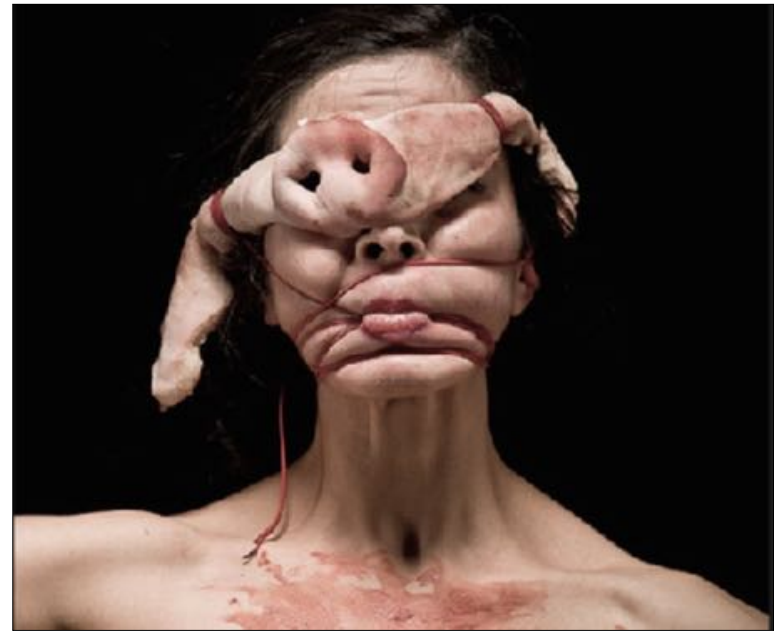

La Pocha Nostra, 2009

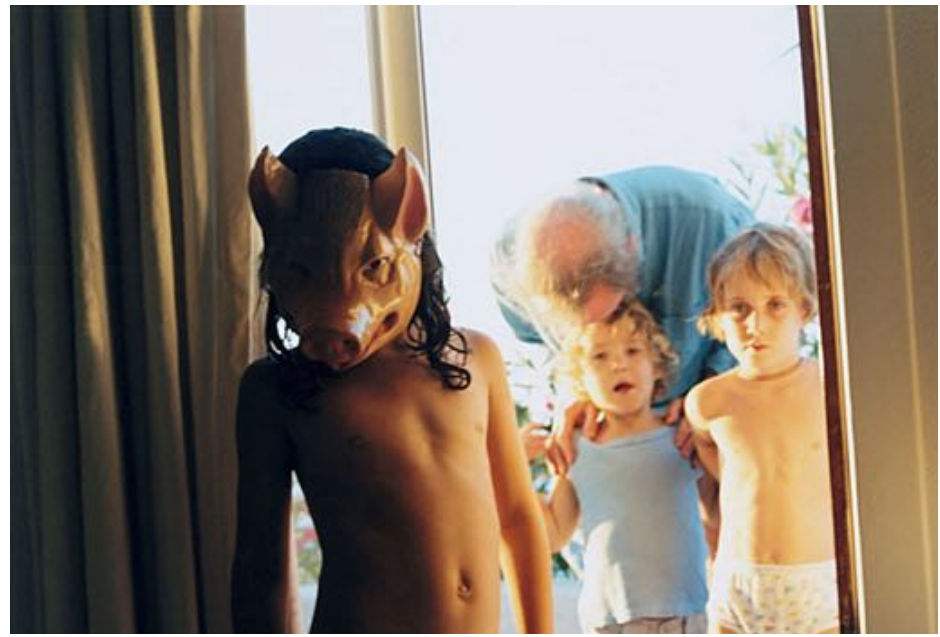

Tierney Gearon, 2000

In my workshop of filthy creation, I recall what I had assumed had been an amalgam of mangled lifeless dumb matter, data lying inert, awaiting reanimation on the dissecting table. Research that seeks recognition as 'quality' produces Frankenstein's monster curated to resemble a recognisable form, but simultaneously and menacingly unraveling the very form it imitates. I begin to sense a formlessness, an in-between-ness, a space that is not easily classified or categorized, and therefore, for now, is rendered unintelligible and monstrous.

I flinch at the discarded bones of the humanist researcher. I realise my (con)fusion with the mangled playground melee and following Haraway, we emerge as hybrid contaminations, in which neither my body, my camera, notepad, child, space and time pre-exist "the relating, and the relating is never done once and for all" (2003: 12). We are each, and all, a writhing mass of visceral intra-activity, neither inert, nor lifeless, but uncannily monstrous figures, infinities, intrinsic perversions. But what can these chaotic spillages $d o$ in the re/unthinking of the playground melee? How can diverse figures be used to restructure and re/unthink quality (in) research? What are the possibilities of living with "severed limbs, a severed head, a hand detached from the arm, feet that dance by themselves" (Freud, 1899/2003: 150), that as Freud suggests, have something highly uncanny about them, especially when they are credited with independent activity? 


\section{Dogfight: the melee of prosthetics}

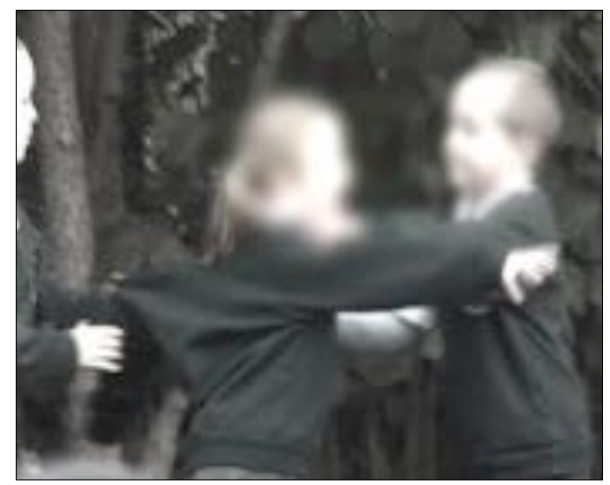

This is play.

This is assault.

This is chase.

This is chaos.

This is violence.

This is exciting.

This is serious.

This is commonplace.

This is deeply curious.

"This is nothing, an instant that expresses the past and the future into which it is divided" (Deleuze, 1990: 62)

Dogfight is the name given to my multiple engagements with this playground game of 'Catch a Girl Kiss a Girl'. Among those many different encounters, I have turned to science, literary studies and in particular, to art so that my body is, for a moment at least, "... directly touched by the forces of chaos from which it so carefully shields itself in habit, cliché, and doxa" (Grosz, 2008: 21). Across many disciplines, the trans-body is flesh torn apart and sewn together again in a shape other than that in which it was. Here, my leanings to monstrosity emerge from trans-disciplinary research, reaching 'across' or 'beyond' in my fight against the swathes of educational logic, rationality and tendencies to return to the intact human form that devour each viewing of Dogfight.

As educational researcher, who is already both monstrous and simultaneously creator of monsters, I desire the promises, pleasures and fantasies of transdisciplinary flows that are always already seeping into my imagination, "intra-actions among... forces that fly in the face of any specific set of disciplinary concerns" (Barad, 2003: 810). As Wolfe (2010) suggests, "it will take all hands on deck... to fully comprehend what amounts to a new reality" (2010: 47). As a queer researcher mongrel, my trans-tendencies allow me to carry what Haraway describes as, "the genes of 'unrelated' organisms [that] simultaneously fit into well-established taxonomic and evolutionary discourses and also blast widely understood senses of natural limit." (1992: 56). The disciplinary, fleshly wounds, orifices, septic sores, interfaces and boundaries, that touch, ooze and leak, beckon my tongue to glide across the seepages. I taste, touch, imagine something different that belongs to noone (Barthes, cited in Clifford and Marcus, 1990: 1). Always being located outside the bounds of the proper, my monstrous trans- research threatens to dissolve the boundaries of the proper, what Shaw (2013) deems the risk-averse straitjacket of REF-able quality research, which, according to Holmwood, is overly concerned with preserving "disciplinary organisation and power" (cited in Shaw, 2013). By revealing an indifference to limits, straying outside familiar boundaries, dripping saliva from my tongue, I sense the potential of corporeal irruption. I begin to think about the always already menacing, leaking other that lies amongst the dangers of unchecked disciplinary domination in what constitutes 'quality' research. 


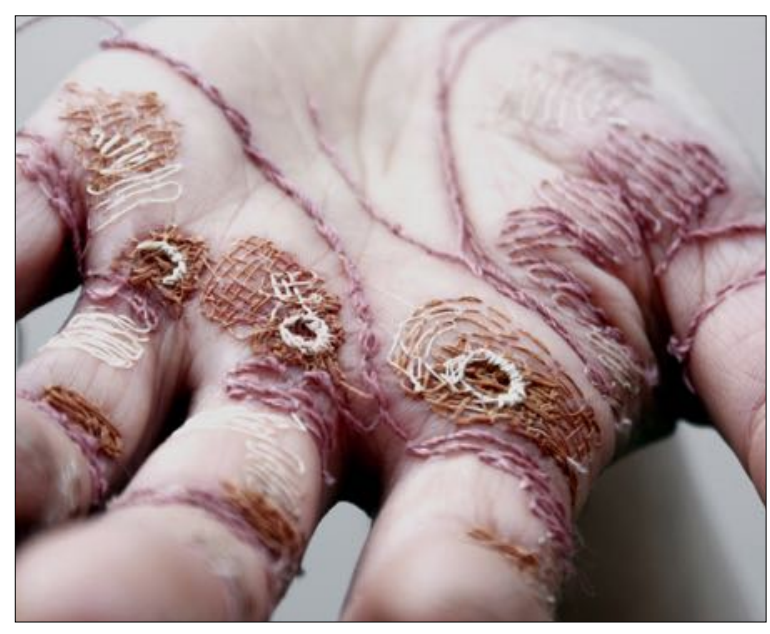

Eliza Bennett, Artist

My figure is beginning to take immense pleasure in, "...the constant merging and reformation of bodies and boundaries" (Shildrick, 1996: 13). At the moment, [transdisciplinary] interfaces seem crude, but like the performance artist Stelarc (1999: 136), I look forward to any unpredictable occurences in those interfaces, moments when transdisciplinary boundaries interrogate their human/nonhuman creators. I look to the re/deforming bodies, drips and flowing matter that seeps from merging bodies, hoping the new formlessness cannot aesthetically contain its own existence, as it seems there, I might find things that are un-representable to themselves, as Guattari might suggest, the affect of [trans-disciplinarity] is viral in nature, known "not through representation, but through affective contamination" (1995: 92). I am struck by how different kinds of intimate leakages might produce and seduce researcher imaginations (Zembylas, 2007, Deleuze \& Guattari, 1977).

I re-imagine the mixtures of the child, the camera, place, time and space, my researcher body, theory, politics, language, as wild prosthetics, perverse severed limbs that dance by themselves. Here, I use prosthetics as assemblages of forms and of formlessness, structured and wild, dislocated, always coming into being as they intra-act with each other.

The evolution of the "prosthesis", not itself living, by which the human is nonetheless defined as a living being, constitutes the reality of the human's evolution, as if, with it, the history of life were to continue by means other than life: this is the paradox of a living being characterized in its forms of life by the non-living - or by the traces that its life leaves in the non-living (Stiegler, 1998: 50).

Stiegler's prostheses are assemblages of forms and formlessness, each demanding attention, agency. Each does not require another body part to function, each does not signal a loss, exposing the human body as lacking, inadequate. I am not trying to assemble the prostheses to resemble or mimic or support anthropocentric form, rendering 
monstrous imitations. Rather the prosthetics I produce are dislocated, nomadic, coming into being as they intra-act with each other (including with the human body), so take form as they connect, disconnect and then reform. So language, clothing, girl, camera-eye are reformed into forms and structures that shape-shift in encounters across the surfaces of Dogfight. Language and voice, although of the throat, produced via biological apparatus that create voice, or of grammar that requires it to function, are prosthetic, free-floating moments of form in surface intensities, instances of intra-action with mouth, tongue, grasp, furore, melee. Prostheses are uncanny chaotic spillages from the fleshly representational shell of the once intact human body (Gigante, 2000: 566). Thinking of the body and prosthetics more broadly, the human body, bodies of knowledge and disciplinary bodies are all trans-bodies, always structures in disintegration, already disassembling, going beyond and exceeding themselves. Among many disciplines, prostheses are usefully monstrous and often used metaphorically to unsettle sedated ideologies. I refuse to analyse Dogfight as a singular body of knowledge(s) supported and made whole by prosthetics.

\section{Trans-encounters: monstrosity and seeping interfaces}

In the playground my gaze is structured via the camera as prosthesis, flaunting enduring patience, chronological endurance, safe distance, irrepressible closeness and endless replay that the combination of my human eye and brain assemblage just cannot offer. As technological extension, it excels. However, can it only ever re-produce what Russell describes as the 'dominant gaze' (1991), the complexities of Mulvey's (1975) masculine gaze and Hall's (1989) critical racial gaze? Can it only ever be what Sofoulis describes as cannibaleye (1988), a gaze that "fucks the world", producing unregulated, new perspectives without clearly defined vantage points? I am standing, watching the playground, momentarily igniting my camera and trying to strike up what Haraway describes as "non-innocent conversations by means of [my] prosthetic devises, including [my] visualization technologies" (1988: 594). I am drawn to the girl being captured and tormented by three boys in the playground game.

As I taste the blood, sweat and saliva of the unfolding Dogfight, fury rises through my body. Following Stryker (2006), if I keep my eye on the girl intensely through the lens, I can deform the images in my passing over them to leave a trace of my fury. I see her mouth, the most living part, the most terrifying. My cannibaleye voice falls amongst discursive screams 'the girl's being swallowed, taunted, goaded, devoured', transforming her flesh into a useful 'girl' prosthesis, making matter have some meaning, her colonized body is palpable, her confinement and tethering is visible. How is the girl's sex (as object of knowledge) constructing me? Why does her sex matter? Flailing around my noticing of her 'sex' are crude renderings of prosthetic feminist discourses. Sofoulis (1988) might say her sex was the raw material, or 'resourced' for its representation as gender. My leanings to biological determinism lie in tension with troubling interfaces of gender. Her body is not allowed not to be a body in my noticing and is always already complex, interfaced with innumerable prostheses - language, voice, skirt, schooling, media, education, and in this excerpt, devoured by my cannibaleye. Haraway's critique of situated knowledges (1988) would keep open the dialectic here, requiring that the girl's sex as an object of knowledge be pictured as an actor and agent, but this is one of many, intra-active, pulsating, vibrating intensities in Dogfight. I allow myself to be touched by, 
and represent playground sexism, violence, misogyny, I take up the anger and frustration that this encounter with Dogfight produces.

I know that politically, a feminist discourse is a prosthetic imperative. Amongst the feminist struggles to dismantle any sense of a wholly 'natural' or 'fixed' category of sex that somehow pre-exists and is a passive basis for the cultural construction of gender, alongside both categories of sex and gender becoming entirely unstable and indeterminate (Webster, 2000: 2), the political power of the feminist movement comes under intense scrutiny. I am cognisant that, "The political for Deleuze would seem to be the excitement of melee and the freedom of experimentation with realms traditionally demarcated from political fora such as the artist or even the sexual" (Flanagan, 2004: 2). I sense Dogfight offers more.

If I rethink my 'body image' as monstrous researcher, my body becomes boundary creature, the cannibaleye is unraveling in the promiscuous encounter between the 'object' and the 'agencies of observation'. The material-discursive entanglement of my body, the camera, the gaze, the forces and debris of a child's body as it is propelled through spacetime produces Dogfight as always coming to be through/in observation, whilst also being devoured by, and devouring the camera/eye in their distributed and singular coconstitution. If I am to experience the camera/eye prosthetic without 'presents', am I able to open up my self and others to radically different ways to think about Dogfight?

Returning to Dogfight, the boy grabs the girl by pulling at her jumper, producing a fibreflesh-affect encounter. Moving fibres with flesh, the wild prosthesis changes shape, stretches to sustain an attachment, a tether, shackle. It creates bodily deformations while simultaneously holding the body in place. Does this tormented prosthesis render the girl subject to particular demands? I lean to Grosz's notion of body image and Haraway's body work, to think about the ways in which a child's "corporeal exterior is psychically represented and lived as an imaginary anatomy" (Grosz, 1994: xii) and wonder what gives a subject her sense of place in the world and her connection to others?

Cold sweat, a racing heart and other bodily impulses take me to a chase, a wild dog being torn apart by a rival group of dogs, their prey, still alive, is gripped around its neck. The loose skin of the neck is extended as teeth bite into oozing, bloody flesh, pulling and contorting it to distort the already broken body. The pack hold on to it as it writhes around in pain, trying to shake itself free, but as blood seeps from gouging wounds in its extended neck, the flailing struggle gradually unfolds into a lifeless body. 

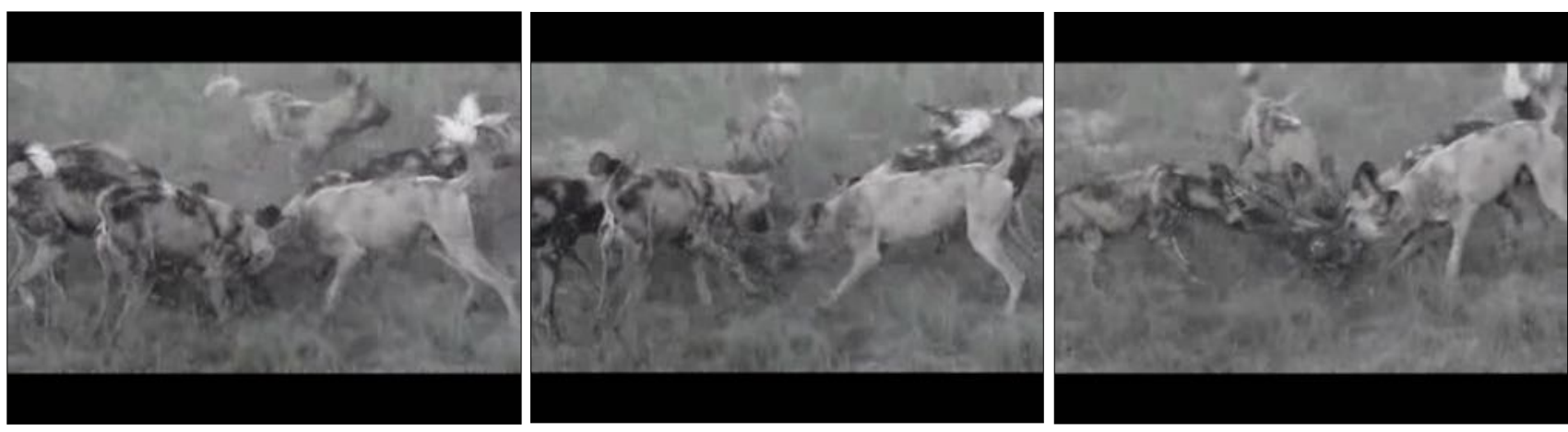

Pack of Wild Dogs kill rival Wild Dog

Suddenly I taste the uncanny reconfiguration of the child-human-animal and the screen becomes momentarily obscured as my tongue moves over your theory once again. Deleuze and Guattari's work opens up "becomings-animal, traversing human beings and sweeping them away" (2004: 237) and Haraway asks, "How would we sort things out? Canid, hominid; pet, professor; bitch, woman; animal, human; athlete, handler" (2003: 1). As I look at the obscured screen, I taste the historical animal work of attachment and personality development (Harlow, 1958; Ainsworth \& Bowlby, 1991), classical conditioning (Pavlov, 1927), imprinting (Lorenz, 1970), operant conditioning (Skinner, 1953), moral development (Kahn, 2003) and studies of aggression (Bandura, 1961) where dogs, rats, chickens, monkeys, cats and Bobo Dolls have co-produced Frankenstein theories.

Simultaneously, the fibre-flesh-affect prosthesis becomes what Massumi describes as a "different logic directly embodied in action, flush with gesture... a lived abstraction" (2014: 9). It is an entangled body-not-body assemblage, mimicking but also menacing (hetero)normative identities, assemblages of authority and power. It draws me into a zone of indiscernibility, animality and politics (Massimi, 2014). Bateson's analysis of animals at play (1979) suggests that in play, as one animal nips the other at the back of the neck, the nip (resembling the lethal bite when fighting), holds the corresponding activities apart - it has the value of the action of a bite in fighting, without its force or function. The mouth nips/bites and tethers the neck of the caught animal, pins her to the ground, causing disempowerment and (con)fusion from behind. Turning back to the fibre-fleshaffect producing the children's play, the hand gripping the jumper's fibres resembles the disorienting and immobilizing nip, yet differs.

Fibre-flesh-affect represents a beginning of the human form in this play event, produced by things as objects-in-phenomenon, offering up comments on what it is doing as it is doing it. Dogfight comments on the analogous gap between sexual battle and play, unfolding a series of commentaries into the playground melee. How does play as prosthesis hold up particular bodies of educational knowledge? Narratives of childhood and sexual innocence render the playground 'play' momentarily safe. Yet, simultaneously, the wild prosthetic gestures of Dogfight inform the play/battle fusion, leaking, and producing it from the inside. Thinking about the furore of the playground melee, Massumi describes how, 
"the envelopment in a nonfighting field of what is proper to the arena of combat, packs the situation. Each act carries a double charge of reality, as what is being done is infused with what would be doing. The situation's actuality swells with possibility" (2014: 9).

The monstrosity of spillages and excesses signal the fibre-flesh-affect charged with intensity, animation, energy and spirit. I am focused on what becomes of the playground melee as the fibre-flesh-affect gesture as play, moves into its analogous function of Dogfight. Where do the charged intensities and actualities swelling with possibilities spill over from play into battle? Are there already leakages of the nonfighting field into the territory of combat? Amongst the swelling of possibilities, Massumi's 'power of variation' (2014: 12) becomes a wild prosthetic, a deformed gesture of always encountering new improvisations, "a veritable laboratory of forms of live action... a margin of maneuver" (2014: 12-13).

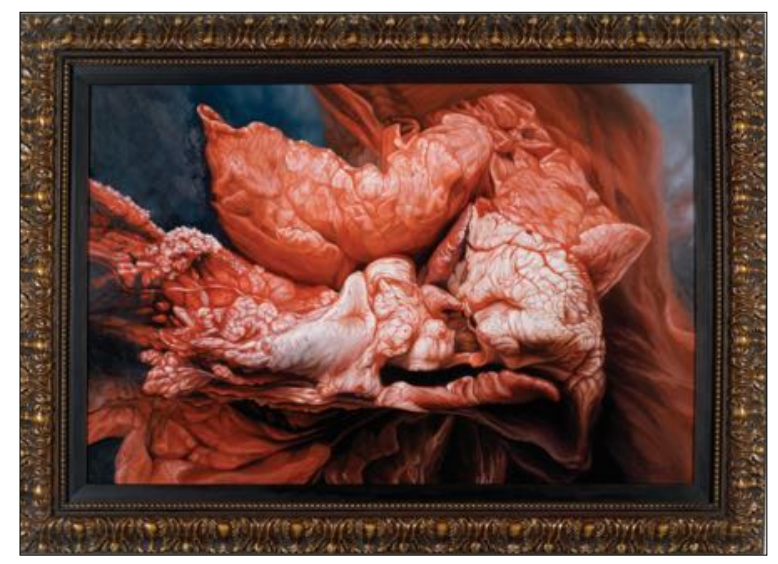

Victoria Reynolds, 2013

Dogfight opens up moments of "expressivity and inventiveness" (Massumi, 2014: 13), where the boundaries of ways of existing, relating and becoming are porous, constantly re-formed. This chance mutation is an adaptation to the singularity of the situation. Perhaps in the play/battle improvisation, the gap produced in Dogfight opens the tethering of the girl to the boy to a series of chance mutations. Disrupting normalizing responses that would otherwise render her subdued gestures vulnerable to prediction, she opens herself to an improvised swelling of possibility: she grips onto a passing second girl who becomes an expressive adaptation, a force with which to propel herself away from the conforming fibre-flesh-affect. Almost simultaneously, another boy opens a 'margin of maneuver': from behind he puts his arms around the waist of the boy who is tethering the girl, pulling him backwards, away from his grip on her jumper. In these adaptive moments, the dual forces function like an instance of Barad's "repulsion at the core of attraction" (2012: 209). Rather than coherent, intact discourses of heteronormative gendered performances constraining this playground event, such improvised chance mutations, produce an unbounded moment swollen with new repulsive prosthetics. The singularity of data's morphology has been ruptured (Ku, 2006: 118). 


\section{Flickering at the edges of blizzards}

Margaret Atwood writes of another familiar monster, "Abominable Snowman-existing and not existing, flickering at the edges of blizzards, apelike man or manlike ape, stealthy, elusive, known only through rumours and through its backward-pointing footprints" (2003: 10). As monstrous researcher I simultaneously exist and do not exist, known only here through my backward-pointing footprints, or perhaps only in representation as second-order intervention, or back-formation (Massumi, 2002). Living with the gruesome blood-swilled floors of the slaughter house and the oozing dissecting slab, I now find myself on the edges of posthuman blizzards, struggling against the new empiricism, posthuman context because I am facing the unknown, which includes me not-yet-knowing-how to research. I am learning 'by grasping [the movement of the context] in practice as signs' (Deleuze, 1994: 23), but my movement does not yet resemble the movement of the posthuman context. The act of learning to re-sense the world of Dogfight cannot be simply the mechanical repetition of certain actions - filming, writing, interpreting - but must rather be the recognition that I am deforming intra-active relationships with the event of the research context itself, which Somers-Hall (2007) suggests is a movement that takes me beyond mere habit.

Returning to the idea of quality (in) research, how can I reconfigure 'quality' to break down the sedentary structures of representation (Deleuze, 1994: 37)? How can I keep myself struggling with, rather than becoming reassured by all-too-familiar representations of quality? If I strive to keep intact and stabilise the very idea of 'quality', hold down the frame that captures the object of study, I am in danger of doing what Semetsky fears, "what will there be left to learn if the difference refers back to some primary identity rather than moving forward to further differences?" (2003: 20), so how can I learn to carry the problem of quality as the unknown along with me (Semetsky, 2003: 19)? Thinking about what I want 'quality' (in) research to be(come), I defend my monstrosity as marker of the paradoxical point. In this scenario, the antagonist of the monster becomes the representative of all that Moretti suggests is "complacent... philistine, and impotent" (1983: 84). If the godlike normalising status of 'quality' is always tied to scientism, rationality and reason, my work here will always be constructed as monstrous in some fashion by being classified and disciplined to determine by contrast a purified (albeit fictionalised) standard of quality (O’Hara, 2003). Haraway (1988) notes the importance of writing essays that constitute arguments against, "...various forms of ... irresponsible, knowledge claims" (1988: 583) as she acknowledges irresponsibility as being unable to be called into account. This paper and Dogfight are attempts to unthink, to "poeticize [my] readiness for a form of being beyond an endlessly self-revising modernity (O’Hara, 2003: 114), without making any irresponsible knowledge claims. They are not the product of escape and transcending limits, but "the joining of partial views and halting voices into a collective subject position that promises a vision of the means of ongoing finite embodiment, of living within limits and contradictions - of views from somewhere" (Haraway, 1988: 590). The monstrosity of this paper lies in its ability to produce 'ontological liminality' (Cohen, 1996), a process whereby the abject or monstrous at work opens up the possibilities of threatening to 'destroy not just individual members of society, but the very cultural apparatus through which individuality is constituted and allowed' (Cohen, 1996: 12). 
Monstrosity takes opportunities to queer specific normalised categories of quality in educational research, "not for the easy frisson of transgression, but for the hope of livable worlds" (Haraway, 1992: 60).

\section{References}

Ainsworth, M. D. S., \& Bowlby, J. (1991). 'An ethological approach to personality development'. American Psychologist, 46, 331-341.

Atwood, M. (2003). Oryx and Crake. US: Seal.

Bandura, A., Ross, D. and Ross, S.A. (1961). 'Transmission Of Aggression Through Imitation Of Aggressive Models'. Journal of Abnormal and Social Psychology, 63, 575582.

Barad, K. (2003). Posthumanist Performativity: Toward an understanding of How Matter Comes to matter. Signs. Spring, pp 801-831.

Barad, K. (2012). On Touching - The Inhuman That Therefore I Am. Differences, 23 (3), pp $206-223$.

Bataille, G. (1930). La Bouche. At http://dmtlsmerz2.wordpress.com/2007/12/23/la-bouchethe-mouth-by-george-bataille-abattoir-angel/. Accessed September 2014.

Berns, U. (2013). 'Artificial Life, Science and Reflexivity in James Whale's Frankenstein', p 187 - 204, in Discovering the Human: Life, Science and the Arts in the Eighteenth and Early Twentieth Centuries edited by Ralf Haekel and Sabine Blackmore, 2013.

Bhabha, H. (1994). The Location of Culture. London: Routledge.

Braidotti, R. (2008). 'In Spite of the Times: The Postsecular Turn in Feminism'. Theory, Culture \& Society, 25 (6), 1 - 24.

Butler, J. (1990). Gender Trouble: Feminism and the subversion of Identity. London:

Routledge.

Clifford, J. \& Marcus, G. (1990). Writing Culture: The poetics and politics of

ethnography. Berkeley: University of California Press.

Cohen, J. (Ed)(1996). Monster Theory: Reading Culture. Minneapolis, MN: University of Minnesota Press.

Deleuze, G. (1985). Cinéma 2: L’image-temps

Deleuze, G. (1990). The Logic of Sense. Trans M. Lester. London: Athlone Press.

Deleuze, G. (1994). Difference and Repetition, trans. P. Patton. New York: Columbia University Press.

Deleuze, G. and Guattari, F. (1977). Anti-Oedipus: Capitalism and Schizophrenia, trans. Robert Hurley, Mark Seem and Helen Lane, New York: Penguin Classics.

Deleuze, G. \& Guattari, F. (1994). What is philosophy? Translated by H. Tomlinson. New York: Columbia University Press.

Derrida, J. (1997). Of Grammatology. USA: The John Hopkins University Press. Flanagan, T. (2004). Deleuze and Politics: some problems and possibilities. Paper presented at the $2^{\text {nd }}$ Pavia Graduate Conference in Political Philosophy. At http://cfs.unipv.it/seminari/flanagan.pdf. Accessed July 2014.

Foucault, M. (1977). Discipline and Punish: The Birth of the Prison. USA: Random House.

Freud, S. (1899/2003). The Uncanny, trans D. McLintock. London: Penguin. 
Gigante, D. (2000). 'Facing the Ugly: The Case of "Frankenstein:'. In ELH, Vol 67(2), pp. $565-587$.

Golding, F. (2012). Ana-Materialism \& the Pineal Eye (Becoming 'Mouth-breast'). In P. Baler (Ed)(2012). The Next Thing: Art in the $21^{\text {st }}$ Century. New York: Little and Brown. Goldstein, A. (Ed)(1991). Martin Kippenberger: The problem perspective. London: MIT Press.

Graham, K. (Ed) (2002). Monstrous Manifestations. US: Inter-Disciplinary Press. Grosz, E. (1994). Volatile Bodies: Toward a Corporeal Feminism. London: John Wiley \& Sons.

Grosz, E. (2008). Chaos, Territory, Art: Deleuze and the Framing of the Earth. US: Columbia University Press.

Guattari, F. (1995). Chaosmosis: an Ethico Aesthetic Paradigm, trans. P. Bains and J. Pefanis. Sydney: Power Publications.

Halberstam, J. (1995). Skin Shows: Gothic Horror and the Technology of Monsters. Durham: Duke University press.

Hall, S. (1989). "Cultural Identity and Cinematic Representation." Framework 36 (1989): 68-81.

Haraway, D. (1988). 'Situated Knowledges: The Science Question in feminism and the Privilege of Partial Perspective'. Feminist Studies, 14 (3), pp 575 - 599.

Haraway, D. (1992). 'The Promises of Monster: A Regenerative Politics for Inappropriate/d Others', pp $295-337$ in L. Grossberg, C. Nelson and P. Treichler (eds). Cultural Studies. London: Routledge.

Haraway, D. (2003). The Companion Species Manifesto: Dogs, People and Significant Otherness. Chicago: Prickly paradigm.

Harlow, H. (1958). 'The Nature of Love'. American Psychologist, 13, p. 673 - 685.

Kahn, P.H. (2003). 'The Development of Environmental Moral identity'. In S. Clayton (Ed) (2003). Identity and the Natural Environment: The Psychological Significance of Nature. London: The MIT Press.

Kim, H. (2007). The Parched Tongue. Accessed at https://www.academia.edu/6320758/The Parched_Tongue, $29^{\text {th }}$ January 2015.

$\mathrm{Ku}, \mathrm{C}-\mathrm{H}$. (2006). 'Of Monster and man: Transgenics and Transgression in Margaret Atwood's Oryx and Crake'. Concentric: Literary and Cultural Studies, 32 (1), pp. 107 133.

LeDuff, C. (2003). 'At a Slaughterhouse, Some Things Never Die', in C. Wolfe (Ed.)(2003). Zoontologies: The Question of the Animal. Minneapolis: University of Minnesota Press, 183-197.

Lorenz, K. (1970). Studies in Animal and Human Behaviour (Vol 1, translated by Robert Martin), Cambridge, MA: Harvard University Press.

Lyotard, J-F. (1979). The Postmodern Condition. USA: University of Minnesota Press.

MacLure, M. (2011). 'Qualitative Inquiry: Where Are the Ruins?' Qualitative Inquiry, 17 (10), pp. $997-1005$

Martin, B.R. (2011). 'The Research Excellence Framework and the 'impact agenda': are we creating a Frankenstein monster?'. Research Evaluation 20(3): 247-254.

Massumi, B. (2014). What Animals Teach Us About Politics. US: Duke University Press. Moretti, F. (1983). 'Dialectic of Fear'. In Signs Taken for Wonders: On the Sociology of Literary Forms, trans S. Fischer, D. Forgacs and D. Miller. London: Verso.

Mulvey, L. (1975). "Visual Pleasure and Narrative Cinema," Screen 16:3, August 1975, 6-18. 
O'Hara, D.T. (2003). 'Neither Gods nor Monsters: An Untimely Critique of the "Post/human" Imagination'. In Boundary 2, 30 (3), pp. 107 - 122.

Pavlov, I.P. (1927). Conditioned Reflexes. London: Oxford University Press.

Rorty, R. (1991). Objectivity, Relativism, and Truth. Cambridge: Cambridge University Press.

Russell, M. (1991). 'Race and the Dominant Gaze: Narratives of Law and Inequality in Popular Film'. In Legal Studies Forum, 15 (3), pp. 243 - 255.

Semetsky, I. (2003). Deleuze's New Image of Thought, or Dewey Revisited. Educational Philosophy and Theory, 35 (1), pp. $17-29$.

Shaw, C. (2013). 'Research that doesn't belong to single subject area is deemed 'too risky' The Guardian, accessed at http://www.theguardian.com/higher-educationnetwork/blog/2013/nov/21/interdisciplinary-research-ref-submission-university, July 2014.

Shelley, M. W. (2008/1818). Frankenstein; Or, The Modern Prometheus. Oxford: Oxford Paperbacks.

Shildrick, M. (1996). 'Posthumanism and the Monstrous Body'. Body and Society, 2 (1), pp. $1-15$.

Skinner, B.F. (1953). Science and Human Behavior. New York: Macmillan.

Sofoulis, Z. (1988). Through the lumen: Frankenstein and the optics of re-origination. University of Santa Cruz, PhD Thesis.

Somers-Hall, H. (2007). The Politics of Creation. In Pli, Vol 18, p 221 - 236.

Stange, M. (2010). "'You must create a female": Republican order and its natural base in Frankenstein'. Women's Studies: An inter-disciplinary journal, 29(3), pp. $309-331$. Stiegler, B. (1994) Technics and Time: The Fault of Epimetheus No. 1. (Trans by R. Beardsworth, and G. Collins). California: Stanford University Press.

Stryker, S. (2006). 'My Words to Victor Frankenstein above the Village of Chamounix: Performing Transgender Rage'. In S. Stryker and S. Whittle (eds). The Transgender Studies Reader. New York: Routledge, pp. 244 - 256.

Van den Belt, H. (2009). 'Playing God in Frankenstein's Footsteps: Synthetic Biology and the Meaning of Life'. Nanoethics, 3, pp. $257-268$.

Weaver, H. (2013) Monster Trans: Diffracting Affect, Reading Rage. Somatechnics, 3 (2), $287-306$.

Webster, F. (2000). 'The Politics of Sex and Gender: Benhabib and Butler Debate Subjectivity'. Hypatia, 15 (1), pp. 1 - 22.

Zembylas, M. (2007). 'Risks and pleasures: A Deleuzo-Guattarian Pedagogy of Desire in Education'. British Educational Research Journal, 33(3), pp. 331 - 347. 